under observation, and specimens of any mosquito larvæ seen collected for identification.

Whether even the 'man-ignoring' $C$. pipiens is likely to breed in the very large outdoor tanks that are now in use is still a matter for speculation. Should such cases occur, the question of applying oil or larvicide merely to allay public apprehension must presumably receive consideration. It has to be noted, however, that oil is extremely injurious to tanks with bituminous linings.

As already mentioned, tank-stored water that is allowed to become contaminated by sewage or other nitrogenous matter will very probably become infested with larvæ of the man-biting species $T$. annulata. Attention has, moreover, been directed to the possibility of tank-stored water becoming a suitable breeding medium for certain of our more 'countrified' species, owing, for example, to algal development or to the accidental or mischievous introduction of vegetable or other organic matter. It is, however, obviously preferable to deal with such contingencies if and when they arise rather than to adopt the spendthrift policy-advocated in some quarters - of indiscriminately treating enormous numbers of tanks on the off-chance of a few of them containing mosquito larvæ. These creatures are so easy to recognize that anyone who has ever seen onewhether in a specimen tube or a tank-can have no difficulty whatever in deciding when anti-larval measures are necessary.

1 Marshall, J. F., "The British Mosquitoes”, p. 319 (British Museum 1938).

${ }^{2}$ Keilin, D., Tate, P., and Vincent, M., Parasitology, 27, 257 (1935).

${ }^{3}$ Marshall, J. F., and Staley, J., NATURE, 135, 34 (1935).

- Roubaud, F., C.R. Acad. Sci., 188, 735 (1929).

${ }^{-}$MacGregor, M. E., Trans. Roy. Soc. Trop. Med. and Hyg., 26, 307 (1932).

- Tate, P., and Vincent, M., Parasitology, 28, 512 (1934).

? Marshall, J. F., and Staley, J., Proc. Roy. Ent. Soc., A, 12, 17 (1937).

8 Marshall, J. F., and Staley, J., Parasitology, 27, 4 (1935).

- Marshall, J. F., and Staley, J., NATURE, 136, 641 (1935).

1o Shute, P. G., Lancet, 1, 6 (1941).

\section{SCIENCE AND WAR*}

\section{By AUSTIN H. CLARK \\ U.S. National Museum}

$\mathrm{F}^{\mathrm{s}}$ ROM the earliest times of which we have a record to the present day, the history of man has been marked by constant changes in the social systems, changes that often were abrupt and violent. One form of social structure or of government has succeeded another. Small but powerful social or political units have grown by accretion or by conquest into great kingdoms or empires. These kingdoms or empires eventually have decayed or fallen apart.

Together with these frequent social, political, or economic readjustments of the past we see a constant and fairly continuous development of other forces which to a large extent are independent of transient political conditions. We note a growing interest in and understanding of the products of the earth and their uses. We also are able to trace the everincreasing subjugation of the forces of Nature, which more and more come to be the servants instead of the enemies of man.

The greatest of all human achievements was the control and use of fire. We have no knowledge of

* Substance of the address of the retiring president of the Washington Acrdemy of Sciences delivered at the 309th meeting of the Academy on January 15. when or how fire was first transformed from a terrifying natural phenomenon into man's most useful servant. Second among human achievements was the fashioning and use of tools and weapons. The origin of the use of tools is lost in the far distant past. Then came the weaving of textiles from plant or animal fibres and the moulding of pottery vessels, followed by the appearance of bronze. Not long after the appearance of bronze utensils of various sorts, the wheel and axle appeared in Asia, soon spreading to Europe.

From the Bronze Age onward the knowledge of the use of natural products and the control of natural forces have shown a fairly continuous development.

Since the beginning of the present century the advance in the knowledge and understanding of the products and forces of Nature has been greater than in all the thousands of years preceding-or at least since the subjugation of fire, the first fashioning of tools, and the domestication of animals and plants.

Whether we like the idea or not, we are now living in an age, and under conditions, in which science plays a dominant part, and the established scientific principles that underlie many of the most familiar of our present-day improvements were unheard of, or considered fallacious, no longer than a generation ago. This is self-evident to all; but the implications inseparable from a culture based ever more intensely and extensively on increasingly abstruse science are not as yet fully appreciated.

The progress that through the ages has been made in the understanding of natural phenomena and in the utilization of natural products is continuing at an accelerated pace, and will continue in the future, in spite of what may happen in the next few years. It may be locally obstructed, or even brought to an end, but somehow, somewhere, it will carry on.

The present struggle is no more a contest in the military field than it is in the field of science. It is quite possible to win the War on the battle front, but lose it in the laboratory. We must see to it that, so far as possible, the steady advance of science is maintained. At the present time we are utilizing to the maximum extent our scientific resources and our scientific personnel to aid in our war effort. But this is not enough. Various branches of science not of immediate military application are in the long run quite as essential for our progress and our welfare as are those forms of engineering, of physics, and of chemistry that underlie the construction and the use of modern implements of warfare. These are the many and varied types of pure science, lines of work leading to results seemingly of no importance, that all too often are regarded merely as a form of mental exercise undertaken solely for the personal satisfaction and gratification of the person concerned. What we call pure science is simply a branch of science for which no economic application has as yet been found. But at any time a body of unco. ordinated facts may suddenly and unexpectedly fit into an integrated whole, to our advantage. Without its advance fringe of competent workers in pure science constantly probing the great unknown and accumulating masses of data with no apparent immediate application, the broader aspects of scientific progress soon would languish. Pure science is likely to suffer severely in times like the present-in times when it would seem to be the wisest course to give it the maximum encouragement.

In the democracies, progress in any line of science is mainly dependent upon the willingness of the people 
to support work in that particular line which, in turn, is dependent upon popular interest and appreciation.

There are people who are by no means scienceminded. Their attitude varies all the way from passive superciliousness to outspoken hostility. We who are engaged in scientific work, and who understand its importance in the general complex of present-day human affairs, often fail to realize how recently science has been able more or less successfully to overcome various forms of popular prejudice and to secure the favour of a very large section of the general public.

The present popular attitude towards science cannot properly be understood without some knowledge of the public attitude in the more or less recent past. I propose, therefore, to digress here in order to indicate briefly the changes that have taken place here and in England since the early days of the settlement of the United States. At that time, in the reign of Queen Elizabeth, Galileo was still a student at the University of Pisa, Tycho Brahe had just completed his observatory, and Paracelsus and Agricola only recently had died. In those days science was almost wholly included in the subject of theology, and scientific work was restricted within narrow bounds by the dogmas of the theologians.

For some time there had been a growing restiveness against the restrictions placed on scientific investigations by the theologians. This restiveness began to take the form of concerted action in the first half of the seventeenth century. As early as the reign of Charles I, about 1645, there existed in England an organization referred to by the Hon. Robert Boyle, seventh son of the first Earl of Cork, as the "Invisible College". This "Invisible College" was first suggested by Theodor Haak (or Hank), a German from the Palatinate, then resident in London. It consisted of weekly meetings at which the results of experimental work in philosophy, in its broad sense, were discussed. This was rather an unorthodox procedure for the time, but those who attended the meetings were among the ablest men of England, and included theologians as well as others. One of the theologians was Dr. John Wilkins, afterwards Bishop of Chester, who had married Robena, sister of Oliver Cromwell. Another participant was Sir Christopher, Wren, who later laid down the plan for the College of William and Mary.

According to Dr. Cromwell Mortimer, "had not the Civil Wars happily ended as they did, Mr. Boyle and Dr. Wilkins, with several other learned men, would have left England, and, out of esteem for the most excellent and valuable Governor, John Winthrop the younger, would have retir'd to his new-born Colony [Connecticut] and there have established that Society for promoting Natural Knowledge, which those Gentlemen had formed, as it were, in Embryo among themselves".

Emigration to America was, however, forestalled. On November 28, 1660, the "Invisible College" became visible as "The Royal Society of London for Improving Natural Knowledge". On the Wednesday following, word was brought that King Charles II approved the design of the meetings; in Oetober 1661, the King offered to be entered as one of the Society; and in the next year the Society was incorporated under the name of the Royal Society, the first charter of incorporation passing the Great Seal on July 15, 1661 .

Although the Royal Society remained in England, both the College of William and Mary and Harvard
College received considerable amounts of money from the estate of Boyle after his death in January 1691-92.

Science now began to assume a now aspect. Charles II had in effect declared that there is nothing irreligious in reporting facts. So records of observed facts and their interpretation in the light of other facts began to supersede introspection in which the aid of facts was regarded as superfluous, combined with interminable commentaries on the works of Aristotle.

Following the Restoration, science in Britain became largely an occupation of the aristocratic and the wealthy, and for the most part was followed along lines that had little or no economic application. In the public mind it came to be identified more or less completely with the aristocracy and to be regarded as partaking of the same aloofness from the general run of human affairs that characterized the social life of the upper classes. The natural result of this was that when, in the Victorian era, the champions of the lower classes began to gain a considerable following, they, or at least many of them, attacked science as one of the perquisites of the aristocracy. This attitude is well illustrated by Charles Dickens's "Mudfog Papers" published on the occasion of the first meeting of the British Association for the Advancement of Science.

Since that time science in England gradually has come more and more into popular favour. Applied science has made rapid strides and is now quite as fully developed and as highly regarded as it is in any other land. The rise in the prestige of applied science, however, has not been accompanied by any noticeable decline in the popularity of pure science, so that here we find the two types advancing side by side in more or less ideal balance. But, unfortunately, science in Britain still does not have the complete confidence of the public, and is not by any means free from neglect, disparagement, or even attack in the popular Press.

In the United States the history of science has been somewhat different. In early Colonial times scientific effort was devoted mainly to making known the natural resources of the new land, particularly the plant and animal life. But applied science early attracted the attention of the colonists. In later Colonial times applied science, especially in certain engineering branches, was systematically discouraged in the fear that the Colonies might become competitors of the mother country in the production of manufactured goods. It was possibly partly as a reaction from this suppression that after the Revolution science stood high in the favour of the representatives of the American people, its most insistent and powerful advocates being Thomas Jefferson of Virginia, Benjamin Franklin of Pennsylvania, and John Adams of Massachusetts. But it was some time before the new country was sufficiently well organized to enable the people to devote much thought to science. When they did, a spontaneous interest, taking various strange and crude forms, appeared, particularly in the agricultural areas. This crude popular science-and pseudo-science-gradually became amalgamated with the more orthodox science of the schools and colleges, and we note, especially after the middle of the last century, an enormous expansion of applied science in all forms, later very largely supported by Federal and State appropriations made possible by active and widespread interest among all the different groups in our population. 
In the United States popular interest in science is twofold, arising both from the vista of economic betterment resulting from applied science, and from its appeal to the imagination. We all like to look forward to the day when we shall be even more comfortable than we are now. But we all have a non-material side. We like to get away from the hard realities of everyday life and to contemplate the unknown, and beyond that the unknowable. We all would like to know more about the world we live in. What would we find a few hundred miles down in the earth, or 20,000 feet below the surface of the sea ? We would like to know more about the stars : Are there any other worlds like ours? And what is it like in interstellar space? We would like to know more about ultimate human origins-indeed, about very many things concerning which our present information is vague and fragmentary. Now although popular interest in science is more general and more widespread in the United States than it is in most other countries, it tends to gravitate in these two directions, towards the directly economic and towards the mysterious. Between these two extremes lies a broad, intermediate field in which the American people as a whole takes little interest, but which is intensively cultivated elsewhere. This is the descriptive branch of pure science, the results of which are of no immediate economic import and are not mysterious.

Popular interest in science must not only be maintained, it must also be increased if we are to hold our own in the years to come, for whether carried on under Government support or in endowed institutions of learning, the full development of our scientific potentialities is dependent upon a sympathetic public attitude. In order to secure, to maintain and to increase public interest in and sympathy towards scientific work, and to convert the still disconcertingly numerous unbelievers, it is essential that we continually provide the public with news regarding scientific progress in all lines of interest to them, from both the material and non-material or philosophical points of view. Such impersonal news is especially desirable in times of national emergency.

Fortunately, in this respect the United States is in an excellent position. More and better science appears in its daily Press and other journals than in those of most other countries, and science is less frequently disparaged and denounced there than elsewhere. For this we have chiefly to thank the National Association of Science Writers, the members of which, in addition to knowing science, know the public mind and are able to present the advances in science in terms everyone can understand.

Progress in science is possible only with the support of an interested and appreciative public. It is also possible only through the efforts of a carefully selected and adequately trained personnel. This is a matter that heretofore has scarcely received the attention it deserves.

At the present time a very serious danger to our continued progress in science has arisen. This is the introduction into the Army of many young men who would be of vastly greater value to the country if they were permitted to continue their studies, or to remain in research positions. The matter is further complicated by the fact that as a rule the most valuable of these young men are those most likely to enlist on their own initiative.

After the War of 1914-18 there was a marked scarcity of able young scientific men. This was most noticeable, perhaps, in the biological sciences, though it was more or less noticeable in other branches as well. Many promising young men were killed. Others, as a result of several years spent in the various armies, found themselves unable to make the necessary readjustment to scientific work. Still others tried to readjust themselves but were only partially successful. Breaking the thread of continuity of effort between the impressionable boy in the formative period and the mature man cannot but result in a certain amount of dislocation. We are reminded of the old Berber proverb :

"Teaching boys is like ploughing earth,

Teaching men is like ploughing rock,

Teaching old men is like ploughing water."

There are two ways out of this dilemma. Either the student may be placed on a deferred list so that he may be enabled to continue his studies uninterruptedly, or he may be assisted in carrying on his work, to whatever degree may be found practicable, while in the Services.

Many young botanists and zoologists would welcome an opportunity for collecting specimens and continuing their studies in regions new and strange to them. Such material as they collected could be sent home to be identified, or to be stored until their arrival. Activities of this nature carried on in their spare hours would go far towards overcoming that feeling of boredom that afflicts almost everyone stationed at an isolated army post or naval base, and there is no reason for believing that these activities would in any way detract from their military efficiency. Not only would this work benefit the men engaged in it ; it would also go far towards filling many gaps in our knowledge of the distribution of animals and plants, and of other features connected with them.

In army posts and naval bases a young zoologist or botanist who spends his spare time catching insects or pressing plants will at first be an object of ridicule to his associates, both officers and men. His situation, however, is by no means without precedent - and most honourable precedent. It may comfort him to realize that the world's leading authority on the Hesperiidæ, a peculiarly difficult group of butterflies especially characteristic of America, is Brigadier General William H. Evans of the Royal Engineers, while in the Royal Navy Rear Admiral Hubert Lynes is the leading authority on a very puzzling group of small African birds. Some time ago the collections of the British Museum were enriched by a fine collection of butterflies presented by Captain Lord Byron. Looking at the matter in a more frivolous light, is a young man using his spare time to continue his studies, and at the same time to advance our knowledge of animals and plants, any more ridiculous than an ancient tough old sea-dog in the forecastle engaged in fine embroidery work with delicately coloured silks, to the accompaniment of blood-curdling oaths ?

A vast amount of such work has been done by the personnel of foreign armies and navies in the past, particularly by officers in the British services. In fact, at one time the United States Navy assigned interested young officers to the Smithsonian Institution for instruction in the collection and preservation of material.

Whether in its material or in its non-material aspects, progress in science is dependent upon the fostering of the scientific spirit. The scientific spirit is more than mere curiosity. It is an insatiable 
curiosity that impels one to learn everything that is known about a given subject, and then to go further and broaden and extend that knowledge by personal investigation and research, in spite of all difficulties and discouragements-and these are always many.

The spirit of science is inborn, though it may appear in anybody, anywhere, in any class, or group, or race. In order to develop the scientific spirit to the maximum, as it must be developed if we are to hold our place in the world of the future, we must watch for it at its inception, and whenever and wherever it is found encourage it.

\section{STATISTICAL CONTROL OF PRODUCTION*}

\author{
By DR. C. G. DARWIN, F.R.S. \\ National Physical Laboratory
}

$\mathrm{F}$

$R$ a number of years I had been interested in the general question of tolerances, first from the point of view of pure science and later in its more practical aspects. My interest in this subject was very much focused when I came to the National Physical Laboratory, where I found that work was being done on the actual verification of manufacturing and inspection gauges; this work, of course, deals with the subject in an enhanced degreesquared, so to speak, because there is not only to be considered the tolerance of the work, but also the tolerances on both the go and the not-go gauges which are to check the work.

From internal evidence of the gauge drawings, it looked as if some of the tolerances were assigned much closer than should be necessary, and I started to try to find out how they had been fixed. To accomplish this, on every occasion when I met an engineer I asked him how he decided the tolerances in his branch of the subject; I fear I bored a great many people at this time. I got a variety of answers which sometimes explained things a bit, but often not at all, and though I discussed it with quite a number of men, many of them occupying prominent places in different branches of the profession, I came away with the impression that scarcely any of them were really interested in the subject of tolerances. To exaggerate the picture which $I$ got as the result of my inquiry, I concluded that in designing a new machine the chief engineer drew it free-hand with dimensions to the nearest inch, and sent it to the draughtsman to work out the detail to the nearest thousandth, who then gave it to his junior assistant to mark in the tolerances. Instructions were certainly always given that tolerances should be as easy as possible, but only lip service was done to them, and the junior assistant, anxious not to get himself into trouble, would, as a general rule, think of the smallest number he knew and then halve it. This is a caricature, of course, and has some of the absurdity of one, but also perhaps just a little of the resemblance. Seriously, it seemed to me that there was a defect in the habit of thought of many in the engineering profession, and that some sort of campaign was needed to inculcate in people's minds the idea that every number has a fringe, that it is not to be regarded as exact but as so much plus or minus a bit, and that

* From a paper before a joint meeting of the Institutions of Civil, Mechanical and Electrical Engineers held on April 15. the size of this bit is one of its really important qualities.

Without any very clear idea of where to catch hold of the subject, I had full intention of trying to do something about it at the time I went to the United States a year ago. There I came across the method of 'statistical control' of mass production, and it was obvious at once that this is the right approach. Similar work has been done in Great Britain too, in particular by the staff of the General Electric Company and by members of the Royal Statistical Society, and it was perhaps ill-luck that I never came across it before crossing the Atlantic ; but that I did not shows that it was not very widely known. I would add that it is not by any means very widely used yet in the United States, though the use is spreading. In both countries it has been principally used in industries associated with electricity, such as the telephone industry, but I want to einphasize that it should be of even greater importance in the mechanical industries, and that it is specially applicable to a business like the manufacture of munitions in all their aspects.

One of the important points in the new method is that it gives reasoned instead of guessed values to the tolerances. I will take as an example the making of time fuses for anti-aircraft, and I am giving away no military secrets in doing so, since I shall invent the data and miss out a lot of other considerations that would really enter. Suppose that the lethal area of a bursting shell is such that, if it explodes within a tenth of a second of the set time, it will make a kill. The gunner therefore demands of the manufacturer that he make a fuse with accuracy a tenth of a second. The manufacturer works out his method, but finds that whereas it is easy to get one to a fifth of a second, he will have a lot of trouble to get to a tenth, and, indeed, he estimates that for the same effort of work and cost he could not hope to get more than a quarter as many fuses if they must have the accuracy of a tenth. Now half his shells will burst within the range I asked for and so, in fact, I shall be wise if I accept his inferior fuse, since I shall thereby get four times as many shells of which half will do what I want, and I shall therefore double the rate of killing. I need not say that $I$ have oversimplified the business; on one side I have missed out the cost of the other parts of the shells, and on the other, I have forgotten that the gunner has uncertainties of range to consider, so that his demand for a tenth of a second is more exact than he can justify for practical use.

My example is intended to show that it is good business for the user and the maker of any article to get together before deciding the tolerances of manufacture. The user may be inclined at first to feel that in doing this he is surrendering some of his freedom of choice, but if you consider it closer you will see that this is not so. He has not got any real freedom of choice, since he must surely try to design the article so as to be as easy to make as possible, but he has foregone the quantitative information of what will in fact prove to be easy, and above all of what thing, easy to make, will be good enough for the job. I may summarize this aspect of the matter by saying that the user has tended to demand that everything should be made for him as well as possible, but he ought to want everything to be made for him as badly as possible, or perhaps not quite that, but as badly as permissible. It is in this aspect that statistical control specially gives the right information. 